\title{
Preliminary report on crustal deformation surveys and tsunami measurements caused by the July 17, 2006 South off Java Island Earthquake and Tsunami, Indonesia
}

\author{
Teruyuki Kato ${ }^{1}$, Takeo Ito $^{2}$, Hasanuddin Z. Abidin ${ }^{3}$, and Agustan ${ }^{4}$ \\ ${ }^{1}$ Earthquake Research Institute, the University of Tokyo, Japan \\ ${ }^{2}$ Nagoya University, Japan \\ ${ }^{3} I T B$, Indonesia \\ ${ }^{4} \mathrm{BP} P T$, Indonesia
}

(Received February 14, 2007; Revised June 16, 2007; Accepted August 7, 2007; Online published September 28, 2007)

\begin{abstract}
A large earthquake $(\mathrm{Mw}=7.7)$ along a plate boundary occurred in the south of Java Island on July 17,2006 , and caused a significant tsunami. We made GPS observations and tsunami heights measurements during the period from July 24 to August 1, 2006. The earthquake seems to be due to an interplate low angle reverse faulting, though there might be a possibility of high angle faulting within the subducting lithosphere. Crustal deformation distribution due to the earthquake, aided by tsunami heights measurements, might clarify which would be the case. We occupied 29 sites by GPS in the area of southern Java encompassing the area from 107.8 E to 109.50 E. These sites were occupied once before the earthquake. However, we were not able to detect significant coseismic displacements. The obtained displacements, most of which span several years, show ESE direction in ITRF2000 frame. This represents the direction of Sunda block motion. The tsunami heights measured at 11 sites were 6-7 $\mathrm{m}$ along the southern coast of Java and indicate that the observed heights are systematically higher than those estimated from numerical simulations that are based on seismic data analysis. This might suggest that fault offsets might have been larger-nearly double — than those estimated using seismic analysis. These results lead us to an idea that the rupture was very slow. If this is the case, the earthquake might have been a "tsunami earthquake" that is similar to the one that occurred on June 2, 1994 in the east of the present earthquake.
\end{abstract}

Key words: Tsunami, tsunami earthquake, Java earthquake, GPS, crustal movement.

\section{Introduction}

Indonesian Islands are located near the Equator spanning from $95 \mathrm{E}$ to $140 \mathrm{E}$ and $8 \mathrm{~S}$ to $8 \mathrm{~N}$. The region is one of the seismically most active areas in the world (Fig. 1). Four major plates: Eurasia, Pacific, Indo-Australian, and Philippine Sea plates merge in this area (Fig. 2). The socalled Sunda block, which is mostly aseismic (or rigid), resides in the center of these four mega plates.

Recent study using GPS suggests that central to western part of Indonesian Islands are on the Sunda block that moves to ESE in ITRF2000 frame, whereas the eastern part of Indonesia is under a complicated tectonic regime (Bock et al., 2003; see Fig. 2). The Indian-Australian plate is subducting from the south with about $60-70 \mathrm{~mm} / \mathrm{yr}$ of velocity beneath Sumatra and Java Islands.

Many destructive interplate earthquakes and tsunami have occurred historically along the Sumatra and Java Islands region, among which 2004 Giant Earthquake and Tsunami (Mw9.3) is one of the largest events in the region (e.g., Ammon et al., 2005; Hashimoto et al., 2006).

After this giant earthquake, the geological activity in the Sumatra and Java region seems to be activated. Another

Copyright (c) The Society of Geomagnetism and Earth, Planetary and Space Sciences (SGEPSS); The Seismological Society of Japan; The Volcanological Society of Japan; The Geodetic Society of Japan; The Japanese Society for Planetary Sciences; TERRAPUB inter-plate earthquake of M8.7 occurred south of the 2004 event, nearby Nias Island, about three months after the 2004 giant earthquake (e.g., Geist et al., 2006). Merapi Volcano erupted in May 2006 and then an inland earthquake of M6.3 occurred in May 262006 nearby Jogyakarta, central Java Island and more than 6,000 people died.

In July 2006, another earthquake occurred in about 200 $\mathrm{km}$ south of Java nearby the Java trench as shown in Fig. 3 and generated significant tsunami. The generated tsunami caused a lot of damage along the south coast of Java Island and hundreds of people were killed by the tsunami centered at Pangandaran beach. Java Island area has experienced a number of tsunami-genic earthquakes in recent years; 1977 Sumba Is. (Mw8.3), 1992 Flores Is. (Mw7.7), 1994 East Java and 1998 Aitape (Mw7.0) in New Guinea are examples (Fig. 3).

\section{2006 July 17 South off Java Island Earthquake} The July 17th 2006 earthquake (Mb6.1, Ms7.7 and Mw7.7, Harvard global CMT) occurred about $200 \mathrm{~km}$ south of western Java Island (see Fig. 3). Yagi (2006) analyzed the seismic wave and suggested that the earthquake occurred along shallow dipping (10 deg) thrust faults and was thus a typical interplate earthquake. Yamanaka (2006), on the other hand, made a similar analysis and suggested the possibility of high angle reverse faulting that occurred within 


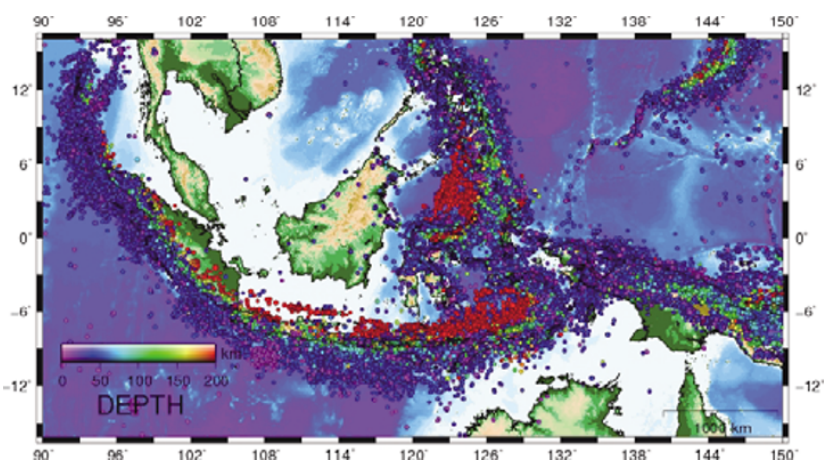

Fig. 1. Seismicity of Indonesia and surrounding region. Data is taken from USGS database ( $\mathrm{M} \geq 3.0)$. Data period is from January 1st, 1973 to December 31st, 2006, and the depth range is from $0 \mathrm{~km}$ to $250 \mathrm{~km}$.

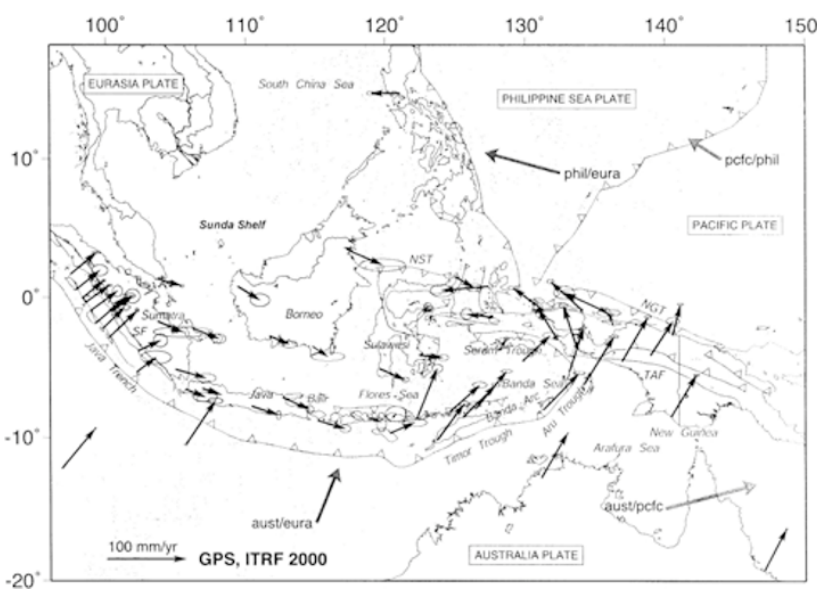

Fig. 2. Tectonic map of the Indonesian archipelago and the Sunda Shelf region (Bock et al., 2003). Labeled, shaded arrows show motion (NUVEL-1A model) of the first-named tectonic plate relative to the second. Solid arrows are GPS velocity vectors for the period from 1991 through 2001, in ITRF2000. Error ellipses indicate 2-D 95\% confidence levels based on the formal (white noise only) uncertainty estimates. NGT, New Guinea Trench; NST, North Sulawesi Trench; SF, Sumatran Fault; TAF, Tarera-Aiduna Fault.

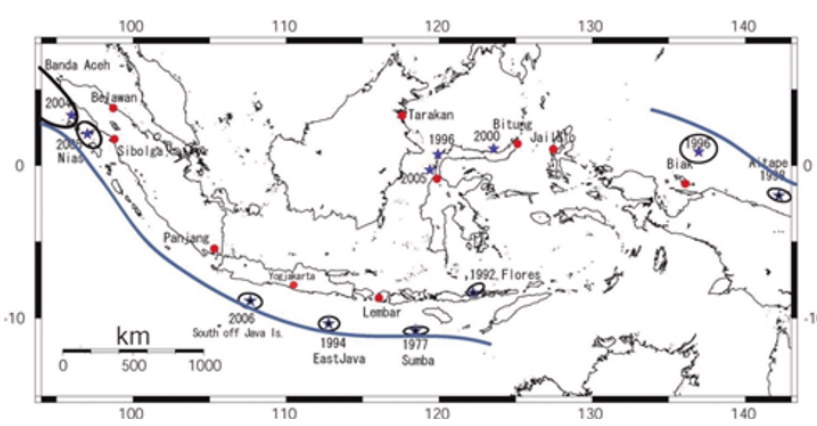

Fig. 3. Locations of recent large earthquakes around Indonesia (after Tsuji et al., 2006). Epicenters are shown by asterisks and tsunami source areas are shown by ellipses.

the subducting slab. The tsunami generation shown in the present study favors the shallow thrust faulting by Yagi.

\section{Field Surveys}

The field survey was conducted as Indonesian-Japanese joint project. Indonesian survey team started GPS measure-

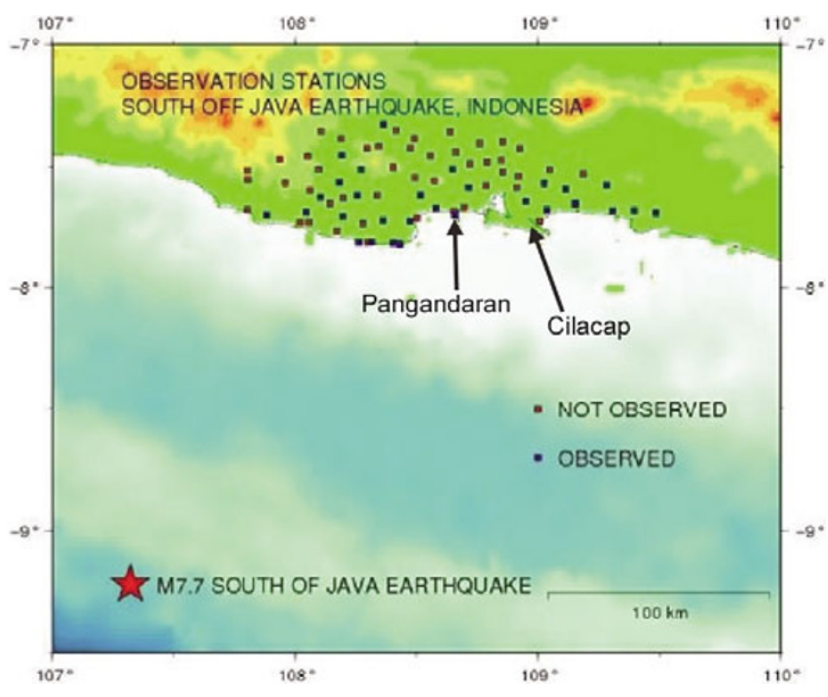

Fig. 4. Surveyed area in this study. Dots are the existing GPS sites, though only sites shown by blue marks are occupied for 2006 GPS observations. Epicenter of the 2006 South off Java Island earthquake is shown by asterisk.

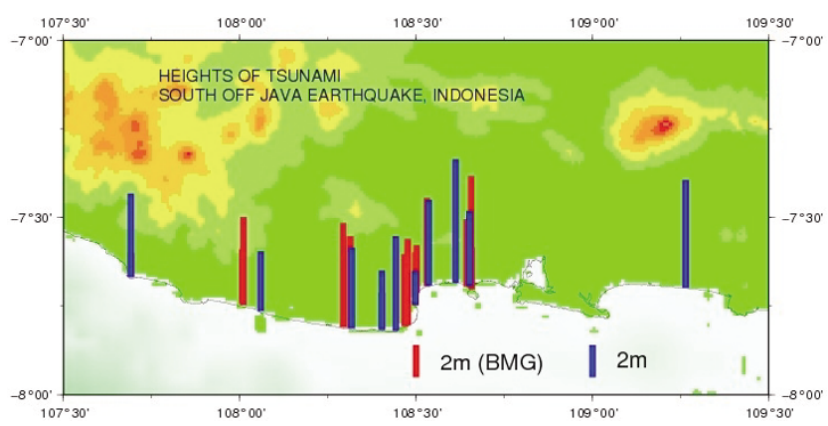

Fig. 5. Graphical presentation of measured tsunami heights. Measured heights are shown by vertical bars; Blue bars are by the present study and red bars are by BMG (Indonesian Meteorological Agency).

ments on July 22nd and Japanese team joined them from July 24th.

We made GPS measurements along the south coast of Pangandaran and the surrounding region, where large tsunami damage was recorded (Fig. 4). Trimble 4000SSI, Ashtech Z-XII and Leica SR9500 receivers were used for observations. Due to limited period of survey, we occupied only about one day at a site.

Along with GPS measurements, we conducted tsunami height measurements and interviews with local residents about earthquake and tsunami. The earthquake occurred in the afternoon at about $15 \mathrm{~h} 19 \mathrm{~m}$ local time, so that most people were awake. However, the shaking from the earthquake seems to have been very small. Most people said that they felt the shake only slightly or did not feel any jolt.

After the survey of about a week, the GPS survey teams returned to Bandung, central Java, on July 30th. On July 31st, we made a small seminar at ITB for discussing about the earthquake and tsunami with researchers and received interview from media.

Old GPS data were obtained through ITB and are now being processed. 
Table 1. Measured tsunami heights. Tidal height were corrected.

\begin{tabular}{|c|c|c|c|c|c|}
\hline Location & Longitude & Latitude & Distance & Tsunami height & Remark \\
\hline Pameungpeuk & $107: 41: 26.6 \mathrm{E}$ & $7: 40: 05.9 \mathrm{~S}$ & $10 \mathrm{~m}$ & $5.98 \mathrm{~m}(\mathrm{I})$ & Water mark on the wall \\
\hline Sindongkarta & 108:03:35.7 E & $7: 45: 52.8 \mathrm{~S}$ & $30 \mathrm{~m}$ & $3.95 \mathrm{~m}(\mathrm{R})$ & \\
\hline Near LGJW & $108: 26: 32.1 \mathrm{E}$ & $7: 49: 10.2 \mathrm{~S}$ & $50 \mathrm{~m}$ & $5.50 \mathrm{~m}(\mathrm{I})$ & Grass on the tree \\
\hline Batukaras & $108: 29: 51.3 \mathrm{E}$ & $7: 44: 48.6 \mathrm{~S}$ & $30 \mathrm{~m}$ & $1.75 \mathrm{~m}(\mathrm{I})$ & Water mark on the wall \\
\hline Pangandaran & 108:39:06.0 E & $7: 41: 37.6 \mathrm{~S}$ & $70 \mathrm{~m}$ & $4.27 \mathrm{~m}(\mathrm{I})$ & Water mark on the wall \\
\hline Dara Payung & $109: 15: 51.8 \mathrm{E}$ & $7: 41: 53.2 \mathrm{~S}$ & $100 \mathrm{~m}$ & $7.39 \mathrm{~m} \mathrm{(I)}$ & Broken roof of a toilet \\
\hline GPS SITE 10471 & $108: 19: 02.6 \mathrm{E}$ & $7: 48: 45.7 \mathrm{~S}$ & $100 \mathrm{~m}$ & $6.23 \mathrm{~m}(\mathrm{I})$ & Indicated water mark \\
\hline GPS SITE 10472 & $108: 24: 11.5 \mathrm{E}$ & $7: 48: 56.2 \mathrm{~S}$ & $10 \mathrm{~m}$ & $1.86 \mathrm{~m}(\mathrm{I})$ & Indicated water mark \\
\hline
\end{tabular}

Tsunami height: (I) Inundated height, (R) Run-up height.

Distance is from the seashore to the measured point.

\section{Tsunami Height Measurements}

We measured tsunami heights from Pameungpeuk (to the west) to Dara Payung (to the east). Table 1 shows the measured tsunami heights. All of measured heights are inundated heights except at Sindongkarta where run-up height was measured. Figure 5 summarizes the measured heights. Blue bars are those we measured and the red bars are the results taken from Fachrizal et al. (2006).

The heights were corrected for tide. The heights vary from place to place and range between 2 meters and 7 meters. It would be noteworthy that high tsunami of bigger than 5 meters are recorded in the whole region. Much comprehensive tsunami measurements were done by other teams and they were integrated by Tsuji et al. (2006). The figure prepared by Tsuji et al. (2006) that includes our results suggests that the tsunami of higher than several meters extended further east to Jogyakarta. Nearly $200 \mathrm{~km}$ of south coast of Java Island was washed by high tsunami of several meters.

\section{GPS Observations and Analyses}

GPS observations were done at 29 sites in about a week. GPS observations before the earthquake were done in the period between 1995 and 2002. However, most of them were either single frequency or else only a few hours of observations. Therefore, it may be difficult to obtain precise site displacements due to the co-seismic crustal deformation.

We are using Bernese Ver5.0 and GIPSY softwares for deriving site positions in ITRF2000 reference frame. Here we show only the results by Bernese software. At this moment, we are not able to obtain results from single frequency data.

Only displacements from seven sites are obtained and their movements are shown in Table 2 and Fig. 6(a). As is shown, the displacement rate since the last survey are several tens of centimeters. Model estimation, for example based on the model by Yagi (2006), suggests only a few centimeters of displacement in the study area. Thus, the observed displacements may not represent the co-seismic crustal motion.

Since the observation period for the last survey was only a few hours, the obtained displacement may be somewhat

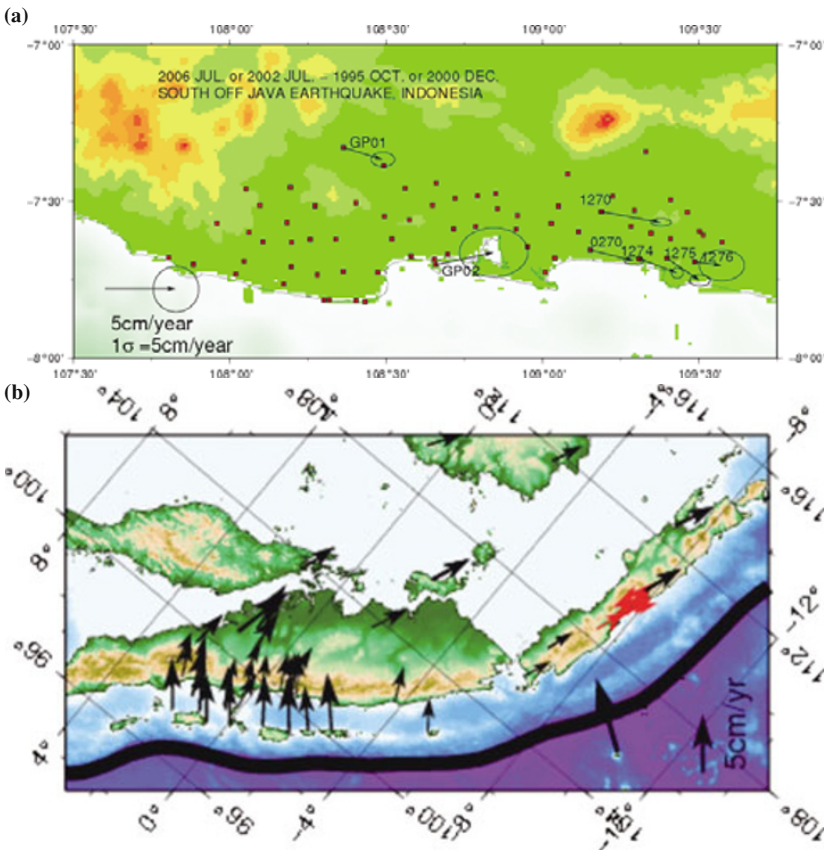

Fig. 6. (a) Estimated site displacement vectors by GPS. Error ellipses are 1 sigma. (b) Velocity vectors compound from Fig. 2 and Fig. 6(a).

biased. Biases in estimating positions of the receiving antenna in case of short observation stem from biased satellite configuration. There are two error types in generating positioning bias due to satellite configuration. One is phase center variation due to different elevation angle of satellites and the other is short term change in propagation delays. Antenna multi-path might cause significant positioning bias if the observation duration is too short. Although it is difficult to evaluate its effect quantitatively, it might amount to a few centimeters. In order to avoid such positioning bias due to short observations, at least 24 hours of observations are necessary to keep the highest accuracy of a few centimeters or better.

However, it is interesting to note that the direction and the velocity of motion which is mostly to east is consistent to the velocity field due to global analysis shown in Fig. 2 (Bock et al., 2003). Figure 6(b) is the combination of Fig. 2 
Table 2. Estimated displacements and velocities at GPS sites.

\begin{tabular}{ccccccccccc}
\hline Site name & Site code & Latitude & Longitude & \multicolumn{2}{c}{ Observation } & \multicolumn{2}{c}{ Displacements (cm) } & \multicolumn{2}{c}{ Rates (mm/yr) } & \multicolumn{2}{c}{ SD (mm/yr) } \\
& & & & periods & EW & NS & EW & NS & EW & NS \\
\hline N10270 & 0270 & -7.6550 & 109.1527 & Oct. 1995-Jul. 2006 & 33.2 & -8.2 & 30.9 & -7.6 & 22.5 & 8.1 \\
PAWALO & 1270 & -7.5322 & 109.1871 & Oct. 1995-Jul. 2006 & 45.2 & -8.2 & 42.2 & -7.6 & 22.2 & 8.2 \\
11274 & 1274 & -7.6841 & 109.3094 & Oct. 1995-Jul. 2006 & 28.6 & -10.6 & 26.7 & -9.9 & 13.2 & 11.1 \\
& 1275 & -7.6819 & 109.3981 & Oct. 1995-Jul. 2006 & 24.8 & -16.7 & 23.1 & -15.6 & 22.3 & 12.6 \\
BUAYAN & 1276 & -7.6928 & 109.4865 & Oct. 1995-Jul. 2006 & 20.5 & -2.7 & 19.1 & -2.5 & 49.6 & 34.3 \\
GPS01 & GP01 & -7.3282 & 108.3632 & Dec. 2000-Jul. 2006 & 15.5 & -4.7 & 27.7 & -8.4 & 25.9 & 15.7 \\
GPS02 & GP02 & -7.7026 & 108.6582 & Dec. 2000-Jul. 2002 & 6.5 & 1.4 & 40.8 & 8.8 & 75.2 & 53.9 \\
\hline
\end{tabular}

and Fig. 6(a) showing that the velocity vectors shown in this study is mostly similar to the previous results by Bock et al. (2003), suggesting that the obtained velocity field in this study seems to reflect interseismic block motion of Sunda block.

\section{Tsunami Simulations}

Koshimura (2006) made some numerical simulations for estimating tsunami heights along the coast based on Harvard CMT solution. Used source parameters are; $(\mathrm{L}, \mathrm{W})=(84.8 \mathrm{~km}, 42.4 \mathrm{~km})$, dislocation $=3.71 \mathrm{~m}$ and depth $=10 \mathrm{~km}$. Two models using different strike, dip and rake of $(289.0,10.0,95.0)$ and $(104.0,80.0,89.0)$ are used according to two possible faults along two nodal planes of Harvard CMT solutions. The former case stands for low angle thrust faulting and the latter case is for the high angle faulting.

His results suggest that low angle thrust faulting generates highest tsunami of about $3.5 \mathrm{~m}$ in the west of Pangandaran area, whereas high angle faults generates only about 3 $\mathrm{m}$ of maximum tsunami. Tsunami does not reach to east of Cilacap due to results of this numerical simulation. Neither of these results predicts observed tsunami heights of about 6-7 meters.

\section{Discussion}

\subsection{Was the earthquake "Tsunami earthquake"?}

The term "tsunami earthquake" is defined as source characteristics which excite a larger tsunami than expected from seismic wave radiation (e.g., Kanamori, 1972). Ruff and Kanamori (1980) suggested that tsunami earthquakes occur at plate boundaries where the plate coupling is weak. GPS results shown in this study suggested that the motion of the Java island is ESE and do not show any influence of the plate convergence of the Australian plate that subducts underneath the Java Island (see Fig. 6(b)). In other subduction areas such as the Japanese Islands, GPS velocity field clearly shows evidence of plate coupling manifested by parallel displacement rate distribution to the plate motion. The velocity field at Java shows motion mostly perpendicular to the plate motion and indicates that plate coupling at the subducting plate interface is very weak. If this is the case, the Java trench along the south of Java is a potential source of tsunami earthquakes. It may be noteworthy that the 1994 Java earthquake that occurred east of the 2006 earthquake was also thought to be a tsunami earthquake.

Another line of evidence is that people along the coast felt only weak ground shake, but suffered from an unex- pectedly high tsunami. Note that tsunami without strong shock does not necessarily indicate that the earthquake is a "tsunami earthquake". The present case seems that the weak ground shake compared with that expected from its magnitude (Mw7.7) strongly indicates that the slip velocity on the surface would be slow enough not to radiate much seismic wave compared with high tsunami. Mori and Park (2006) suggested that the rupture velocity of the earthquake was about $1 \mathrm{~km} / \mathrm{s}$ in average based on back-propagation analysis of P-wave seismograms. This rupture velocity is much slower than the normal earthquake that usually shows 2-3 km/s. Fujii and Satake (2006) suggested that the 2006 Pangandaran earthquake was a "tsunami earthquake" based on inversion analysis of tsunami waveforms recorded at six tide gauges. This is consistent with the present results.

Koshimura's simulation suggests that the earthquake was on the lower angle thrust faults in favor of Yagi's model. Also, the simulation suggests that the source model by the seismic wave analysis cannot explain the observed tsunami heights of more than 5 meters, particularly to the east of Cilacap to Jogyakarta. The fault surface seems to be much wider to east and the fault offset would have been larger. Thus, we could conclude that the earthquake was a "tsunami earthquake"

\subsection{Significance of post-seismic crustal deformation studies}

Recent studies of crustal movement indicate that a slow slip around an asperity might have significant role in earthquake generation. Miyazaki et al. (2004) found that the post-seismic crustal movement of 2003 Tokachi earthquake is due to a slow slip on the plate boundary, whose area is complementary to the area that slipped co-seismically (called an "asperity"). They argue that this may be due to the different slip property in terms of rate-and-state dependent friction law. Interesting to note is that an earthquake of magnitude bigger than 7.0 occurred in the area adjacent to this post-seismic slip about one year after the 2003 Tokachi event. This suggests that the occurrence of earthquake might be triggered by such slow event. Considering the importance of post-seismic crustal deformation to the mechanism of earthquake generation, we plan to repeat the GPS measurements in the Pangandaran area in the future. As was indicated, the Java trench south Java is an area of cocern for future earthquakes - probably "tsunami earthquakes". Delineation of slow slip on the plate interface might find any significant slip before the future earthquake. 


\section{Conclusion and Remarks}

The survey immediately after the 2006 South off Java Is. earthquake showed that the tsunami heights along the south Java coast are several meters and are much higher than predicted by the source model derived from seismic wave analysis. Therefore, the earthquake may be considered as a "tsunami earthquake" as was the case of 1994 East Java earthquake. GPS measurements showed cumulative displacement of several to about ten years that might be due to Sunda plate motion. The co-seismic displacement cannot be seen in the observed displacements.

Considering the importance of slow slip monitoring toward the next adjacent earthquake, we plan to repeat GPS surveys for delineating post-seismic crustal movement in the south Java region.

Acknowledgments. We are grateful to the member of ITB for assisting the GPS observations in the study area. Thanks are also due to Mr. Sugeng Pribadi of BMG who kindly allowed us to use their measured tsunami data. Professor Yasutaka Ikeda of the University of Tokyo and Professor Masataka Ando of Nagoya University kindly provided us equipments for measuring tsunami hights and Professor Tsuji of ERI kindly provided his Power Point file for this presentation. Professor Shun'ichi Koshimura of Tohoku University gave us invaluable comments to his numerical simulation. The authors would like to express sincere thanks to all of them. The present research was partially supported by the funding from the Disaster Prevention Research Forum and by Japan Society for the Promotion of Science through the 21st Century COE Program.

\section{References}

Ammon, C. J., C. Ji, H.-K. Thio, D. Robinson, S. Ni, V. Hjorleifsdottir,

H. Kanamori, T. Lay, S. Das, D. Helmberger, G. Ichinose, J. Polet, and

D. Wald, Rupture process of the 2004 Sumatra-Andaman earthquake, Science, 308, 1133-1139, 2005.

Bock, Y., L. Prawirodirdjo, J. F. Genrich, C. W. Stevens, R. McCaffrey, C.
Subarya, S. S. O. Puntodewo, and E. Calais, Crustal motion in Indonesia from Global Positioning System measurements, J. Geophys. Res., 108, 2367, doi:10.1029/2001JB000324, 2003.

Fachrizal, Sugeng Pribadi, and Iwan Hermawan, Laporan survey gempabumi dan tsunami selatan Jawa Barat, 17 Juli 2006, 31 pp, 2006.

Fujii, Y. and K. Satake, Source of the July 2006 West Java tsunami estimated from tide gauge records, Geophys. Res. Lett., 33, L24317, doi:10. 1029/2006GL028049, 2006.

Geist, E. L., S. L. Bilek, D. Arcas, and V. V. Titov, Differences in tsunami generation between the December 26, 2004 and March 28, 2005 Sumatra earthquakes, Earth Planets Space, 58, 185-193, 2006.

Hashimoto, M., N. Choosakul, M. Hashizume, S. Takemoto, H. Takiguchi, Y. Fukuda, and K. Fujimori, Crustal deformations associated with the great Sumatra-Andaman earthquake deduced from continuous GPS observation, Earth Planets Space, 58, 127-139, 2006.

Kanamori, H., Mechanism of tsunami earthquakes, Phys. Earth Planet. Int., 6, 346-359, 1972.

Koshimura, S., http://www.tsunami.civil.tohoku.ac.jp/hokusai2/disaster/ 06_Java/July17_Java.html, 2006.

Miyazaki, S., P. Segall, J. Fukuda, and T. Kato, Space time distribution of afterslip following the 2003 Tokachi-oki earthquake: Implications for variations in fault zone frictional properties, Geophys. Res. Lett., 31, L06623, doi:10.1029/2003GL019410, 2004.

Mori, J. and S. Park, Estimates of rupture propagation for the July 17, 2006 West Java Tsunami earthquake, in the Programme and Abstracts, The Seismological Society of Japan 2006 Fall Meeting, A066, 35, 2006.

Ruff, L. and H. Kanamori, Seismicity and the subduction process, Phys. Earth Planet. Int., 23, 240-252, 1980.

Tsuji, Y., S.-S. Han, Fachrizal, I. Gunawan, and T. Kato, Distribution of run-up heights of the tsunami of the South off Central Java Earthquake of July 17, 2006, in the Programme and Abstracts, The Seismological Society of Japan 2006 Fall Meeting, C02, 79, 2006 (in Japanese).

Yagi, Y., http://www.geo.tsukuba.ac.jp/press_HP/yagi/EQ/20060717Jawa/, 2006.

Yamanaka, Y., http://www.eri.u-tokyo.ac.jp/sanchu/Seismo_Note/2006/ EIC181.html, 2006.

T. Kato (e-mail: teru@eri.u-tokyo.ac.jp), T. Ito, H. Z. Abidin, and Agustan 